\title{
Communications
}

\section{Swiss Heart Foundation}

\section{Research Prize 2019}

The Swiss Heart Foundation awards an annual prize of 20,000 CHF for one or several outstanding publications / accepted manuscripts of scientific research in the field of prevention, diagnosis and/or treatment of cardiovascular diseases.

Swiss researchers or research teams working in Switzerland or abroad as well as foreign researchers working in Switzerland are entitled to participate. The age limit is 45 years at the time of application. Previous prize winners are not eligible for the prize. In addition, scientific publications, which have already been awarded or elected for another prize, are not eligible. The prize winner will be chosen by the Research Committee of the Swiss Heart Foundation. For further informations and detailed rules see www.swissheart.ch/researchprize.

Applications should be submitted by 31st December 2018 (date of postmark) by post (one copy) as well as by e-mail with:

- one signed accompanying letter

- the publication(s) / accepted manuscript(s) to be considered

- list of references
- brief Curriculum Vitae (max. 1 page)

- summary of your scientific work (2 pages) to:

Swiss Heart Foundation

Research Committee

Dufourstrasse 30

P.O. Box 368

3000 Bern 14

Phone: 0313888080

Fax: 0313888088

E-Mail: research[at]swissheart.ch www.swissheart.ch/researchprize

\section{Sujet d'actualité en ligne} www.bullmed.ch/fr/tour-dhorizon

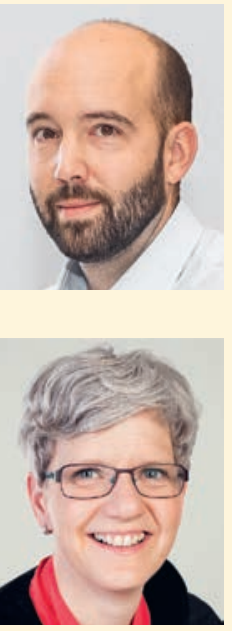

Interview du Dr sc. Dominik Glinz, Institut d'épidémiologie clinique et de biostatistique de l'Université de Bâle

\section{Il est possible d'améliorer l'usage des antibiotiques}

Une étude menée en Suisse à l'échelle nationale révèle qu'il est tout à fait possible d'améliorer l'usage des antibiotiques dans les cabinets des médecins de famille.

Sandra Ziegler, présidente de la direction de EMH Editions médicales suisses SA

\section{«La qualité est notre plus grande force»}

Nouvelle direction pour les Editions médicales suisses. 